\title{
Asia Minor Refugee Associations in Lesvos (1914-1936)
}

\author{
Afroditi Pelteki \\ University of the Aegean, School of Social Sciences, Mytilene, GREECE \\ Department of Social Anthropology and History
}

Received: 27 November 2020 • Accepted: 28 December 2020 • Published Online: 30 December 2020

\section{Abstract}

This paper focuses on the formation and dynamic of the Asia Minor refugee association in Lesvos island (in Greece), during two historical periods: the period known as the First Persecution (Protos Diogmos, in Greek) (1914-1918) and the interwar period (1922-1936). Collectivities of first refugee generation are transformed into communities, unions and associations at the host country (Lesvos), trying to integrate into society and constitute their social reality, structuring new collective identities, collective memories and historical conscience. The present case study relies on primary sources and archival material. It provides us the possibility of both comparative study and exploration/analysis of Asia Minor's refugee association development, since it constitutes part of an ongoing research regarding the Asia Minor Refugee Memory, resulting through genealogical succession within the Asia Minor's Refugee Associations institutional context, in Lesvos.

Keywords: Asia Minor, Refugee Associations, Lesvos, collective identity, historical conscience, collective memory, transformation, generation, First Persecution, interwar.

\section{Introduction}

The present paper aims to the emergence of Asia Minor refugee association in Lesvos, through which the refugees' efforts are drown to respond to the difficulties they confronted during the two periods of their settlement on the island, the hopes and actions of returning to their place of origin and finally the efforts to maintain the Asia Minor conscience and memory of the lost homeland. It is dated on both the First Persecution period (1914-1918), since the first refugees' arrival in Lesvos until their repatriation and the interwar period (1922-1936), since the second refugees' arrival until Metaxas' dictatorship.

The loss of homeland, the traumatic experience of expulsion, the lack of property and means of livelihood, the cautious (if not hostile) attitude of the locals and the weakness of financially exhausted and politically divided Greek state to directly confront their needs, forced Lesvos refugees to self-organize. Since the beginning of their settlement, this first refugee generation created associations, which turned into vehicles of solidarity, philanthropy, social networking, refugee representation, spiritual cultivation and carriers of the Asia Minor memory and conscience.

Although Greek literature and research have been extensively involved with the Asia Minor refugee association in Greece, the absence of Lesvos case study is felt, even though the

(C) Authors. Terms and conditions of Creative Commons Attribution 4.0 International (CC BY 4.0) apply. Correspondence: Afroditi Pelteki (PhD Candidate), University of the Aegean, School of Social Sciences, Department of Social Anthropology and History, Mytilene, GREECE. E-mail: apelteki@sa.aegean.gr. 
island, as a geographical border between Greece and Asia Minor, received large refugee flows in 1914 and 1922, through which significant refugee associations were subsequently formed.

The present case study relies on archival findings. The Refugee Associations Archive at Greek State Archives (Department of Lesvos), the local press of the time, the refugee communities' books in Mytilene and the Ministry of Healthcare book provides invaluable information for the topic.

2. Lesvos as part of the homogenized national space, border between East and West and carrier of the past to the present

Since the $19^{\text {th }}$ century Asia Minor had been celebrated in the Greek national narrative as part of the imagined homogenization of the national space, since it comprised the physical territory (in which resided for centuries) hundreds of thousands Greek - speaking Orthodox Christians, until they were forced to abandon their homeland in 1922-1923. Asia's Minor idea was deeply intergraded in the structure of Modern Greek identity, occupying a significant place to the contemporary Greek imaginary, while the Great Catastrophe [the compulsory movement of the Greek-Turkish population, as a result of the Greek-Turkish War (1919-1922)] is widely considered as a central turning point in Greek history. ${ }^{1}$ The Greek-Turkish Exchange of Population and the Treaty of Lausanne, which were signed respectively on the $30^{\text {th }}$ of January and on the $24^{\text {th }}$ of July in Switzerland, sealed the last tragic chapter of the Asia Minor Campaign. As a result, 1.3 million Orthodox Greek refugees arrived in Greece, ${ }^{2}$ who were uprooted from the coast of Asia Minor and the inner region of Anatolia, while 350.000 Muslins, mostly from Macedonia and Thrace, followed the opposite direction. ${ }^{3}$

Eventually, the signing of the Treaty of Friendship (1930) in Ankara, between Greece and Turkey, was the last act of Asia Minor Hellenism drama, since it signaled the final fee of the return to homeland. 4

The period between 1915 and 1936, known as National Schism, was stained from the deep clash between Royalists (King Constantine I) and Liberalists (Prime Minister Eleftherios Venizelos), regarding Greece's participation in World War I. Although both political poles theoretically shared the same passion for the Great Idea (Megali Idea in Greek), they differed on how it should be executed. While Venizelos declared his commitment to irredentism from the very beginning of his national political career, the Royalists were not willing to fight for this nationalist vision. ${ }^{5}$

${ }^{1}$ Exertzoglou, Haris (2016). Children of Memory: Narratives of the Asia Minor Catastrophe and the Making of Refugee Identity in Interwar Greece. Journal of Modern Greek Studies, 34(2), pp. 343-366, p. 343. https://doi.org/10.1353/mgs.2016.0030.

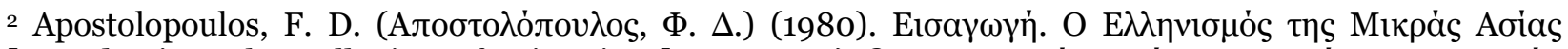

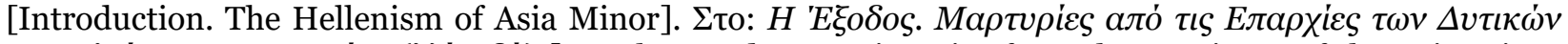

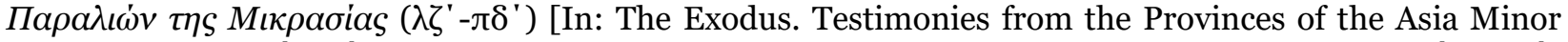
West Coasts (pp. $\left.\lambda \zeta^{\prime}-\pi \delta^{\prime}\right)$ ], F. D. Apostolopoulos (Ed.). Athens: Centre of Asia Minor Studies, Vol. A', p. $\pi \alpha^{\prime}-$ $\pi \beta^{\prime}$.

3 Pentzopoulos, Dimitris (1962). The Balkan Exchange of Populations and Its Impact on Greece, Paris: Muton, p. 69.

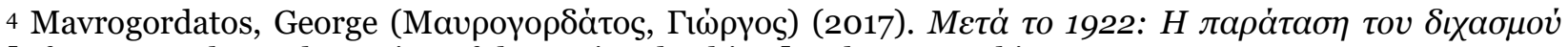
[After 1922: The prolongation of the National Schism]. Athens: Patakis, p. 165-166.

5 Mavrogordatos, George (1983). Stillborn Republic: Social Coalitions and Party Strategies in Greece, 1922-1936. Berkeley: University of California Press, pp. 25-101. 
Lesvos is the third largest Greek island and is located northeast of the Aegean Sea, facing Ayvalik, on the Turkish coast. Its annexation to Greek State (1912) transformed it, from undivided geographical territory with Asia Minor coast and central strategic point of the commercial network of the Ottoman Empire, into alienated border of the Modern Greek State. The Treaty of Lausanne and the Greek-Turkish Exchange of Population (1923) permanently cut off the relations between Asia Minor and Lesvos, while the displacement of Asia Minor Hellenism from homeland (1913-1914 and 1922-1923) turned the island into a host of large number of refugees.

Today, Lesvos stands as a "border" between Europe and Asia. Traces and remains from Ottoman and Asia Minor refugee past are still scattered in the streets of Mytilene, the capital city of the island, designating it into a carrier of "historical past" to the present. 6 This "historical past", almost stable and unchangeable as a whole, is supplemented with Asia Minor post-memory7 (transgenerational transmission of memory), which is still defused to families and communities with Asia Minor place of origin, while the embodiment of refugee memory to "invented traditions"8 (mnemonic practices and representations) and to artificial memory substitutes (Asia Minor Refugee Associations, monuments and museums) transforms the island into "site of memory" maintaining a sense of historical continuity.

Almost a hundred years later, Lesvos has, become again place of reception (since 2015) of large migration flows from Asia and Africa, a fact which makes it an example of repeating history within a different historical context.

3. Asia Minor refugee association at First Persecution period in Lesvos (1914-1918)

The first major refugee crisis which Lesvos faced in the $20^{\text {th }}$ century, known as the First Persecution (Protos Diogmos in Greek) (1913-1914), a result of the tension in Greco-Turkish relations, transformed Mytilene into a "refugee city". ${ }^{10}$ About 100.000 Christian refugees from Asia Minor arrived on Lesvos, ${ }^{11}$ so it was deemed necessary to transfer them to other parts of Greece. Refugees often refused to leave the island with the hope of a short repatriation, since the political evolutions in Greece (Venizelos victories, the territories' annexations etc.) encouraged the hope of returning home, while the proximity and the visual contact with the Asia Minor coast made easier the adaptation to the host place. ${ }^{12}$

Refugees' arrival created many problems like illegitimacies between refugees, ${ }^{13}$ their registration by region of origin to the refugee lists, the housing, the alimentation, the hygiene and

6 White, Hayden (2014). The Practical Past. Evanston: Northwestern University Press; White, Hayden (2010). The Practical Past. Historein, 10, pp. 10-19. https://doi.org/10.12681/historein.2.

7 Hirsch, Marianne (2008). The Generation of Postmemory. Poetics Today, 29(1), pp. 101-128. https://doi.org/10.1215/03335372-2007-019.

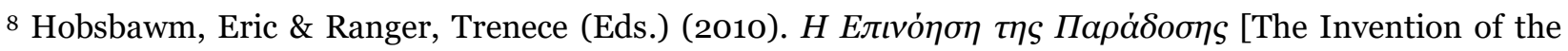
Tradition]. Athens: Themelio, p. 9-10.

9 Nora, Pierre (1989). Between Memory and History: Les Lieux de Mémoire. Representations, 26, pp. 7-24. ${ }_{10}$ Data obtained from Mytilene's Sorority School, Register of pupils 1914-1915 and 1915-1916. Greek State Archives, Department of Lesvos.

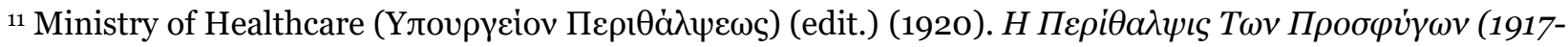
1920) [The Refugees Healthcare (1917-1920)]. Athens, p. 171-172.

${ }^{12}$ Ibid., p. 173-174.

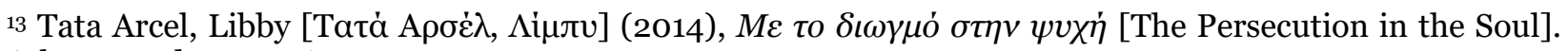
Athens: Kedros, p. 164. 
their dilution ${ }^{14}$ to the island's countryside or to other territories of Greece. The charity of the local Lesbian society, the Greek State through both the local authorities and the Ministry of Healthcare (The Central Committee for Refugee Care in Mytilene) and the local press, were the first aids at the beginning of those chaotic conditions. ${ }^{15}$

The enforcement of an immediate solution impelled refugees of Mytilene to selforganize, grouped by regions - communities of origin and forming "Sections". Their committees were recognized by the General Administration. ${ }^{16}$ Their aim was both the protection and the support of refugee personal needs and issues, in a climate of legitimacy and national discipline, keeping distance from political competitions. ${ }^{17}$ The repatriation itself was one of the main purposes. ${ }^{18}$

Meanwhile, the Central Committee for Refugee Care (established in 1914 and consisted (among others) of the finest refugee social class), divided Lesvos Refugee Prefecture into fifteen sub-refugee regions.

The region of Mytilene consisted of ten refugee "Sections" by region - community of origin. Every "Section" had:

(1) Its own resister.

(2) Its own official recognized committee by the Central Committee for Refugee Care, consisted of each region's trusted refugees, having the responsibility of the certification of refugee identity, the refugees' financial state and the provision of information to the Central Committee.

(3) The committees' responsibilities were extended to fellows refugees where resided on Lesvos villages.

(4) The committees' members constituted the plenary session of the "Pan-Asia Minor and Thracian Union" (Pammikrasitiki and Thrakiki Enosi in Greek).

At Lesvos villages, which belonged to other sub-refugee regions, there were subcommittees, composed of reputable refugees or locals, having the responsibility of reporting refugee issues to the Refugee Care Committee. ${ }^{19}$

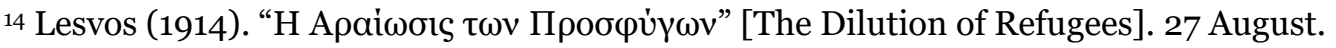

15 Indicative press articles: Lesvos. (1914). "Meүád $\Sigma \kappa \varepsilon \dot{\psi \varepsilon \iota \varsigma, ~ A v a ́ \gamma \kappa \eta ~ \Sigma v \sigma \sigma ı т i \omega v " ~[B i g ~ J o u r n a l e s e ~ R e s e a r c h ~ o f ~ L e s v o s . ~ T h i n k s ~ a n d ~ T h o u g h t s, ~ N e e d ~ f o r ~ F o o d ~}$

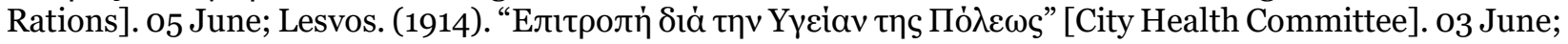

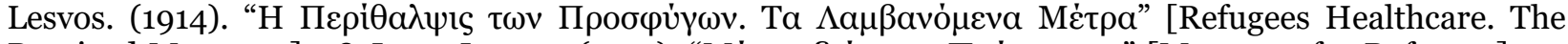

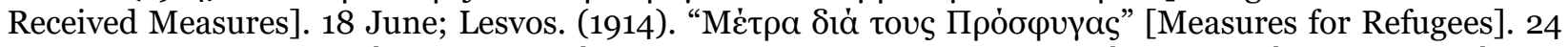

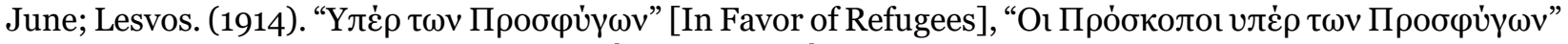
[The Scouts in Favor of Refugees]; " $\Delta \omega \rho \varepsilon \alpha \dot{~ \varepsilon ı ৎ ~ t o u s ~ П \rho o ́ \sigma \varphi v ү a s " ~[D o n a t i o n ~ t o ~ R e f u g e e s] . ~} 27$ June.

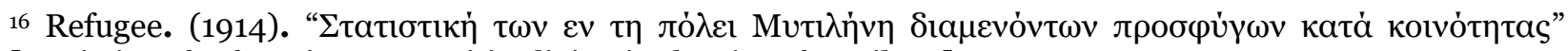
[Statistics of refugee's communities living in the city of Mytilene]. 04 August.

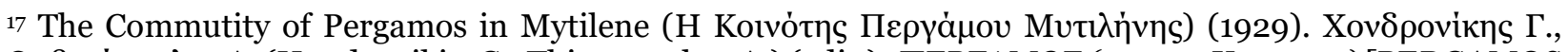

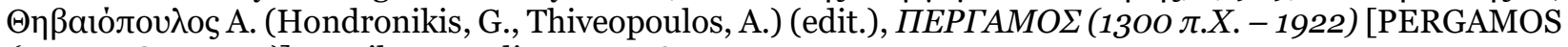
(130o B.C. - 1922)], Mytilene: Melissa, p. 108-109.

${ }^{18}$ Ministry of Healthcare, Op. cit., p. 173-174; The Committees of Asia Minor Refugees in Mytilene (Yлó $\tau \omega \mathrm{v}$

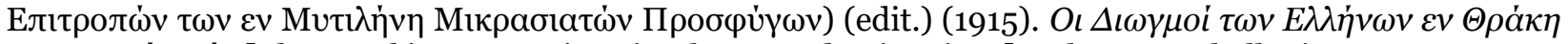

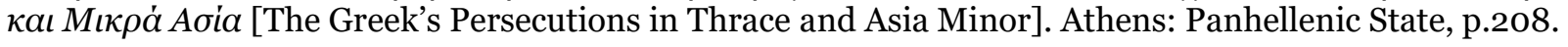

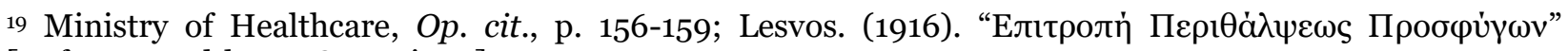
[Refugee Healthcare Committee]. 30 May.
} 
The Refugee Sections of Mytilene, forming special committees, protested and submitted memoranda of their sufferings to local and state authorities and published books. ${ }^{20}$ These were conscious practices through which they seek to promote the Greekness of their place of origin, their justification from the Turkish persecution and their return to their homeland.

During their first settlement in Mytilene, refugees continued to set up official recognized refugee committees by place of origin by the General Administration of Mytilene, aiming at the union between them, the acquisition of respect of the Greek State Administration and the legal mediation between the refugees and the state agencies. The process was initiated by the committee of each refugee community, convening an assembly of its members. When the members of the Governing Council were elected, they presented themselves to the supervisory local authority, in order to announce the committee's recognition. At the beginning of each year, each committee was obliged to update the activities of the previous one, to submit an annual balance sheet and to elect a new committee. ${ }^{21}$

The 281/1914 law was a milestone to Greek association. ${ }^{22}$ In 1916 was officially recognized, by the First Instance Court of Mytilene, the "Pan-Asia Minor and Thracian Union". It consisted of the local refugee committees, which were functioned as coordinating association bodies officially recognized by the General Administration. After being closed for many years, it was officially dissolved by a decision of the Court of First Instance in $1957 . .^{23}$

At the period 1918-1919 the coveted repatriation was achieved. Many refugees returned back to their homeland (approximately 10.000), while many of them began much earlier secretly their departure, due to the slowness of the legal formulations. ${ }^{24}$

\section{Asia Minor refugee association in interwar Lesvos (1922-1936)}

The second and greatest crisis was the result of the Greek's army defeat by the Kemalist forces in 1922, incentivized the execution and persecution of the Orthodox Christian Greek population. Until 1923, it is estimated that about 1.3 million Orthodox Christian refugees arrived and permanent settled in Greece from the Turkish cost and inner Anatolia. ${ }^{25}$

The years that followed found Greece in a state of constant political turmoil. The country continued being divided between Liberals and Royalists and experienced government changes and political instability, which eventually led to the Republic toppling, the restoration of the Monarchy in 1935 and the Metaxas dictatorship in $1936 .{ }^{26}$

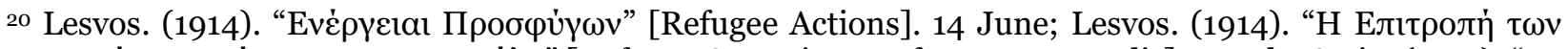

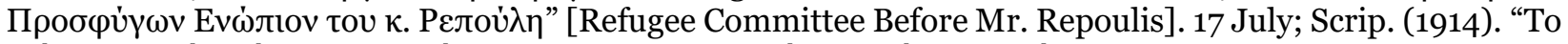

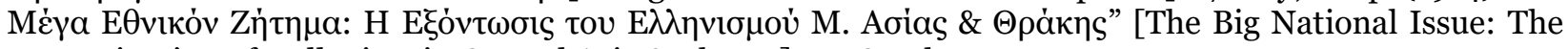
Extermination of Hellenism in Central Asia \& Thrace]. o9 October.

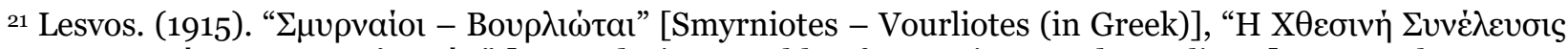

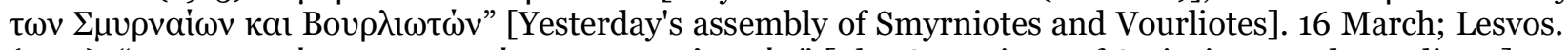

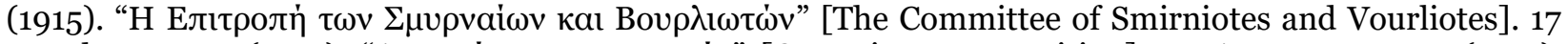

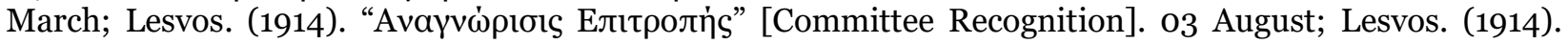

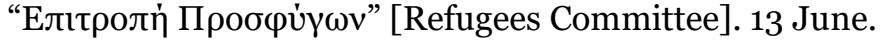

${ }_{22}^{2}$ The law 281/1914 “about associations", Government's Newspaper 171 (1914), pp. 893-899, regulates for the first time the status of associations.

23 Refugee Associations Archive, Greek State Archives, Department of Lesvos.

24 Ministry of Healthcare, Op. cit., p. 201-203.

25 Apostolopoulos, F.D. (1980), Op. cit., p. $\pi \alpha^{\prime}-\pi \beta^{\prime}$.

${ }^{26}$ Exertzoglou, Haris (2016), Op. cit., p. 344.
} 
The flow of the refugees and the exchangeables had a great impact in social, financial and political life of Greek State, a fact which affected Lesvos also. It became both bridge for the passage to Greece and shelter for a new start and better life. Thousands of people arriving to the island by any vessel, while the image of chaos and madness was transmitted from the local press. ${ }^{27}$

According to the official census in 1923, it is estimated that the settled refugees in Mytilene were 21,515, while the sum of Lesvos population was raised to 57,508. The census of 1928 shows that Mytilene came to accommodate refugee inhabitants that comprised almost half of its population, while at the same time, compared to other islands, it gathered the largest percentage of refugees (46.6\%). ${ }^{28}$ The bourgeois refugees were settled mainly in Mytilene and urban environments, while the farmers were absorbed by the Lesbian countryside. ${ }^{29}$

The impending social and economic upheaval cultivated insecurity and suspicion in the society of Mytilene, while the state financially destroyed and politically divided, was unable to face the magnitude of the disaster and insufficient to face the refugee needs.

Since the beginning of the refugee settlement on the island, invitations are registered in the local press for gathering refugees of local origin for the election of new members and the organization of the Committees, while the General Administration of Mytilene reactivated the refugee committees from the First Prosecution, whose representatives were called upon to form the Pan-Asia Minor Refugee Committee. $3^{30}$ Their aim was to find solutions to the primary and immediate problems of refugee feeding, housing and caring. The Committees cooperated with the General Administration of the prefecture of Lesvos and the Pan-Lesbian Refugee Committee (Pallesviaki in Greek) to defend the refugee interests, the issue certificates for benefits and the compensation. ${ }^{31}$

Subsequently, the committees by place of origin were transformed into communities by geographical region and acquired legal status, as the period between 1923-1936 were officially recognized as associations by the Court of First Instance based in Mytilene. At the Greek State

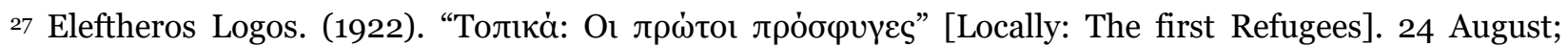

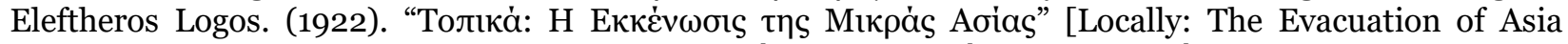

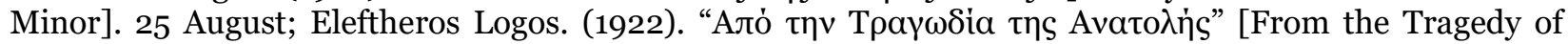

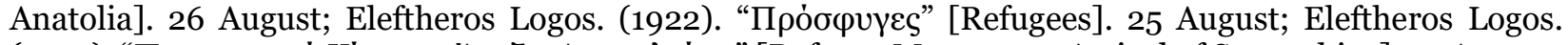

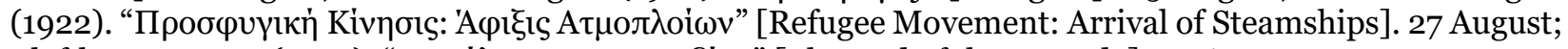

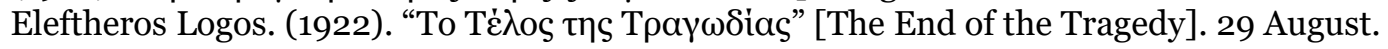

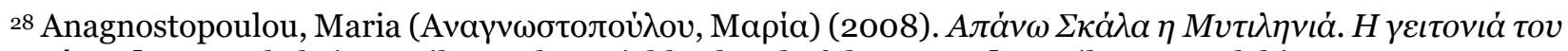
oveipov [Apano Skala in Mytilene. The Neighborhood of the Dream]. Mytilene: Entelehia, pp. 38-50.

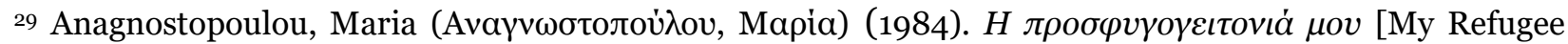

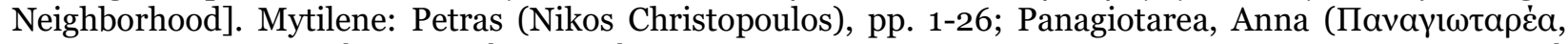

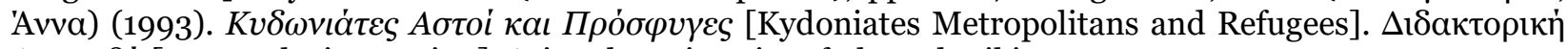
$\Delta \mathrm{l} \alpha \tau \imath \beta \dot{\eta}$ [Doctoral Dissertation]. Aristotle University of Thessaloniki.

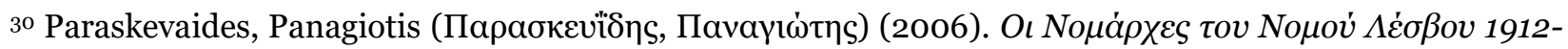
2006 [The Prefects of Prefecture of Lesvos]. Mytilene: Prefecture of Lesvos, pp. 28-29; Salpigx. (1922).

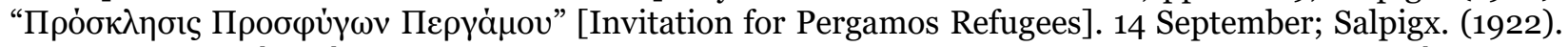

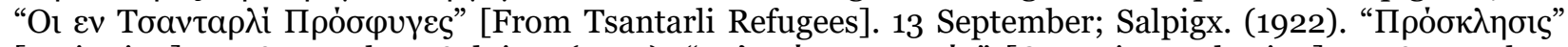

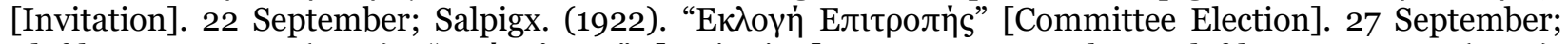

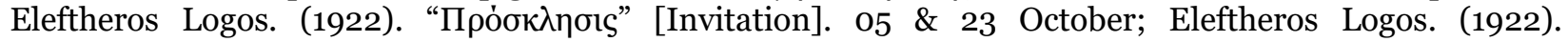

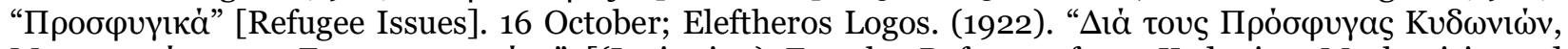

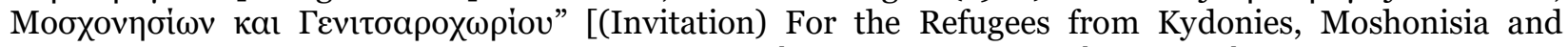

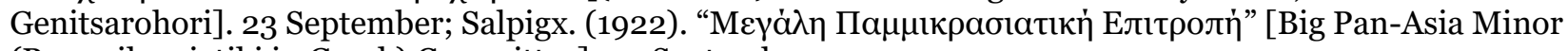
(Pammikrasiatiki in Greek) Committee]. 24 September.

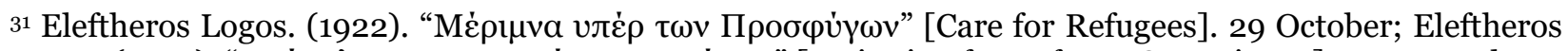

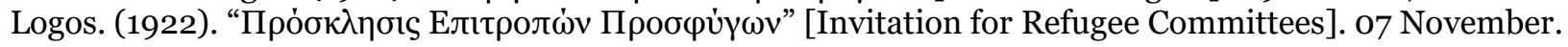


Archives were recorded 14 officially recognized refugee associations by place of origin, which according to their statutes, their aim was charitable, spiritual and not political. Their presidents formed "Lesvos Refugee Union" (Enosi Prosfigon Lesvou in Greek), which according to the statute (1924), had sections in all the villages and refugee settlements of Lesvos. Next to the associations by place of origin in Mytilene, showed up for the first time 17 officially recognized refugee settlements / housing associations, professional associations, political and sports associations, while in the Lesbian countryside showed up 12 officially recognized refugee associations based on the regional community, which they belong. ${ }^{32}$

The term "association" [somatio ( $\sigma \omega \mu \alpha \tau \varepsilon i o)$ in Greek], required by law, was officially used in the documents by the Court of First Instance, however in the titles of those organizations,

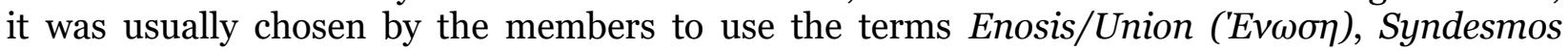
( $\Sigma \dot{v} v \delta \varepsilon \sigma \mu o \varsigma)$ or Syllogos ( $\Sigma \dot{v} \lambda \lambda o \gamma o \varsigma)$.

According to their statutes and depending on the type of association, they aimed: to provide moral and material assistance to the poor refugees of their community, at solidarity with refugees from other communities and peaceful coexistence with indigenous peoples, in the pursuit of refugee rehabilitation and compensation, in improving members' housing, in the establishment of state settlements for the housing of the homeless, in the pursuance of public utility projects, in the pursuit of acquaintance and fellowship between members, so that develop solidarity and address their interests, to collect and publish history material on refugee activities before the Asia Minor Catastrophe, so that preserve the conscience of origin and the sacred memory of those slaughtered in 1922, the establishment of a purely refugee library and the erection of monuments in memory of the lost homelands and the massacre of 1922.33

The majority of the associations, became inactive or self-dissolved during Metaxas dictatorship period (1936-1941) and German Occupation in Greece (1941-1944), while it was officially dissolved by the Court of First Instance of Mytilene in the 1950s. 34

\section{Epilogue / Conclusions}

The formation of the Asia Minor refugee associations was a result of the refugee crisis, which was faced by the Lesbian society and consequently the Greek State in 1914 and 1922, which is part of a broader historical context, the First World War and the Greek-Turkish War.

The formation of Asia Minor refugee association in Lesvos was the beginning of the formation of new social identities. The term "refugee" 35 didn't just function as an autonomous distinct entity, but also as a member of a wider social group, collectivity or "imagined community", ${ }^{6}$ in which were participated and interacted individuals with common origins,

${ }^{22}$ Refugee Associations Archive, Greek State Archives, Department of Lesvos.

33 Ibid.

34 Ibid.

35 The term "refugee" is significantly wide and refers to those who are forced to abandon their homes, both because they are forcibly expelled or their residency poses a threat to their lives and prosperity. Violent or forced refugee displacement might be linked to religious, ideological, political, economic, national and

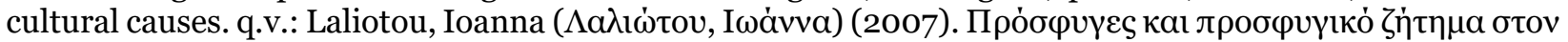

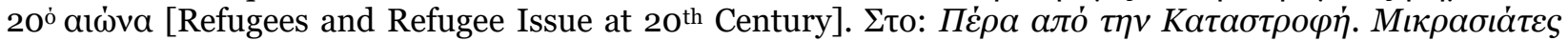

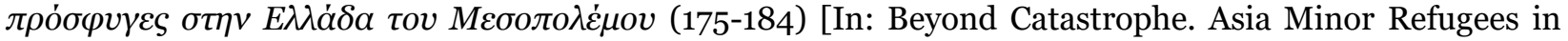
Interwar Greece (pp. 175-184). Tsedopoulos, George (edit). Foundation of the Hellenic Word. Athens: $2^{\text {nd }}$ Edition, p. 175 .

${ }^{6} 6$ The term belongs to Benedict Anderson, who employs the term "imagined political community" to define the nation. In the case of the refugees there is not an issue of nation-building. The application of the term is 
experiences, memories, goals, aspirations, expectations, building the basis of a new "collective identity and conscience", a "refugee discourse" and the context of a "public sociality". A process which "the individuals who were involved enter into relations in the public sphere in the name of a culturally defined relevance, develop various forms of collective action and they invest them with cultural meanings, on the basis of which they form collective identities and subjectivities". ${ }^{37}$ At the same time, they constitute their social reality, manage their daily life and become active aiming at their integration into Greek society, constructing a refugee public discourse and the rebirth of the refugee memory, which they intend to maintain and reproduce.

Nevertheless, the construction and reproduction of a uniform refugee identity was extremely complex. On the one hand, internal differences and distinct local identities could not provide a common ground for creating a homogenized group; on the other hand, the traumatic experiences of the Greeks of Asia Minor were not of the same quality and intensity for the refugee population as a whole. ${ }^{8}$

The emergence of a specific refugee ideology was necessary in dealing with these difficulties. The nostalgia for the "lost paradise" and the idealization of life in Asia Minor became an essential element of this ideology and served as a defensive psychological response to the frustration, the poor living conditions, the social racism, the mistreatment by the natives and the inability of the state to solve their problems. In other words the "Unforgettable Homelands" narrative laid the foundations for building a unique refugee identity, utterly different from the

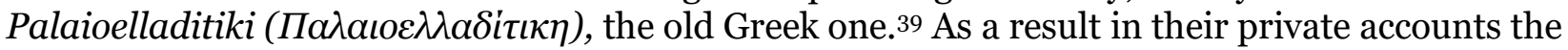
refugees stress their local origin (Pergaminoi, Kydoniates, Smyrniotes, Vourliotes etc.), whereas in public sphere they fall under the more general category of "refugee Hellenism". The registration of the Greek refugee narrative into the national narrative, led to the gradual refugee integration in the Greek nation and eventually the refugee identity became an integral part of the Greek national identity. ${ }^{\circ 0}$ Since 1930 the terms of social integration have led to the formation of a distinct, diverse, non-politicized refugee identity, which communicates with the national as an organic part.

Until the 1980s, the final awareness of non-return gave the "lost homelands" a symbolic and nostalgic tone, through songs, novels and the cultivation of the Asia Minor cultural

used in order to set the boundaries of the reconstruction of their social network in Greece-Lesvos. q.v.: Anderson, Benedict (1991). Imagined Communities: Reflections on the Origin and Spread of Nationalism. London: Verso Books.

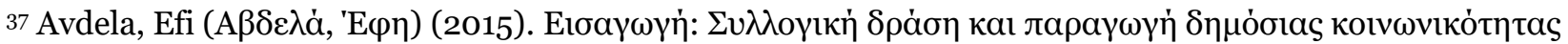

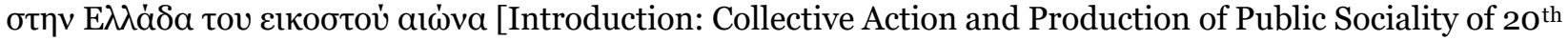

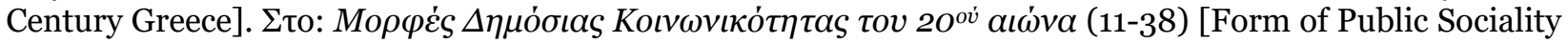
in $20^{\text {th }}$ Century Urban Greece (pp.11-38)]. Avdela, Efi, Exertzoglou, Haris, Liritzis, Christos (edit). Athens: Anagramma, p. 22.

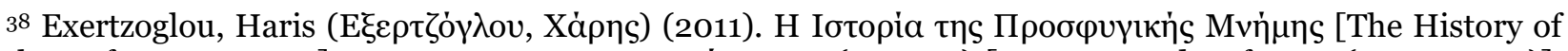

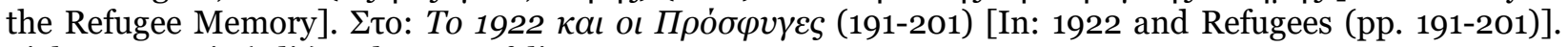
Liakos, Antonis (edit). Athens: Nefeli, p. 132.

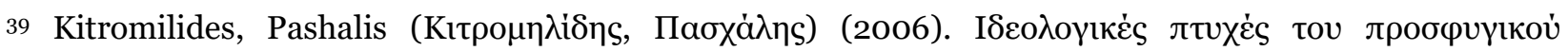

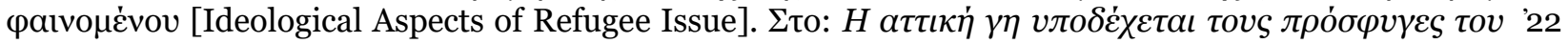
[In: Attica Land Welcomes Refugees of ' 22]. Karapanou, Anna (edit). Athens: The Hellenic Parliament Foundation, pp. 42-43; Hirschon, Rene (1989). Heirs of the Greek Catastrophe. The Social Life of Asia Minor Refugees in Piraeus. Oxford: Clarendon Press, p. 17; Kamouzis, Dimitris (2016). Collective Representation, Memory and Refugee Identity: Asia Minor Greeks After 1923, Athens: Center for Asia Minor Studies, p.8. Published in Turkish: Kamouzis, D. (2016). KOLEKTIF TEMSIL, HAFIZA VE MÜBADILL KIMLİĞI: 1923' TEN SONRA KÜÇÜK ASYALI RUMLAR. Yllında Türk-Yunan Zorunlu Nüfus Mübadelesi Yeni Yaklaşımlar. Istanbul: Yeni Bulgular.

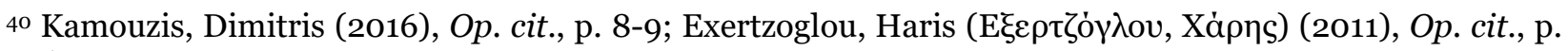
196. 
"tradition", while in the 1960 s and the Political Changeover (Metapolitefsi in Greek) the presence of Asia Minor becomes felt in cinema, music and literature. ${ }^{4}$

At the same time, the collective refugee organization experienced great growth, as a number of new associations were created throughout Greece and in Greek communities abroad. These associations usually have a reference point of specific places of origin, which are imagined connected the second and third refugee generation, cultivating distant culture aspects through dance, music and other cultural events. $4^{2}$

In Lesvos, the formation such as refugee associations concerns the period since $1980 \mathrm{~s}$ onwards therefore is initiative of the second and third refugee generation.

\section{Acknowledgements}

This research did not receive any specific grant from funding agencies in the public commercial, or not-for-profit sectors.

The author declares no competing interests.

\section{References}

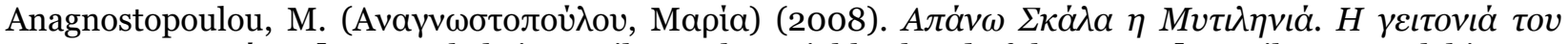
oveipov [Apano Skala in Mytilene. The Neighborhood of the Dream]. Mytilene: Entelehia.

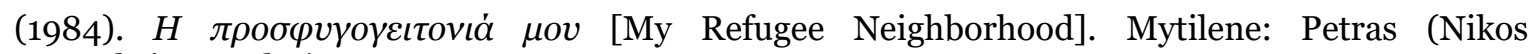
Christopoulos).

Anderson, B. (1991). Imagined Communities: Reflections on the Origin and Spread of Nationalism. London: Verso Books.

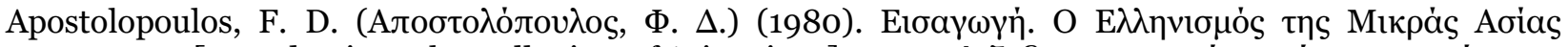

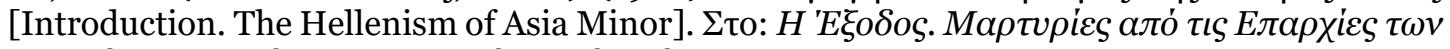

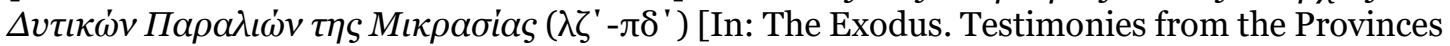
of the Asia Minor West Coasts (pp. $\left.\left.\lambda \zeta^{\prime}-\pi \delta^{\prime}\right)\right]$, Apostolopoulos, F. D. (edit). Athens: Centre of Asia Minor Studies, Vol. A' .

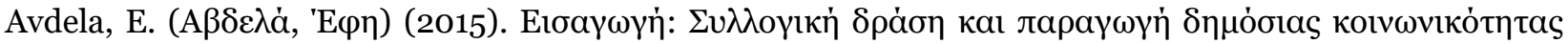

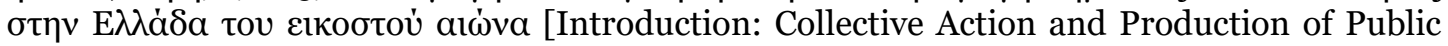

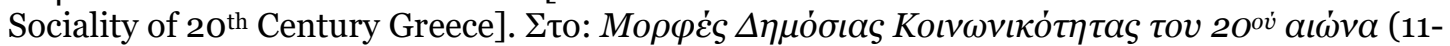
38) [Form of Public Sociality in $20^{\text {th }}$ Century Urban Greece (pp. 11-38)]. Avdela, Efi, Exertzoglou, Haris, Liritzis, Christos (Eds.). Athens: Anagramma.

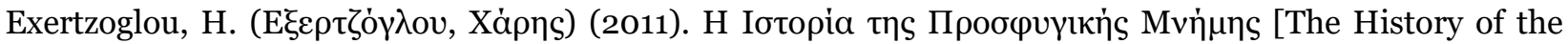

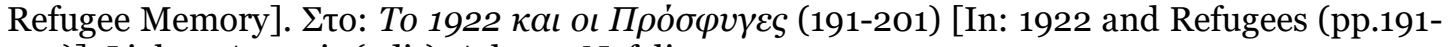
201)]. Liakos, Antonis (edit). Athens: Nefeli.

(2016). Children of Memory: Narratives of the Asia Minor Catastrophe and the Making of Refugee Identity in Interwar Greece. Journal of Modern Greek Studies, 34(2), 343-366. https://doi.org/10.1353/mgs.2016.0030.

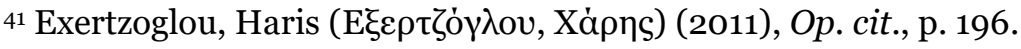

${ }^{42}$ Ibid. 
Hirsch, M. (2008). The Generation of Postmemory. Poetics Today, 29(1), pp. 101-128. https://doi.org/10.1215/03335372-2007-019.

Hirschon, R. (1989). Heirs of the Greek Catastrophe. The Social Life of Asia Minor Refugees in Piraeus. Oxford: Clarendon Press.

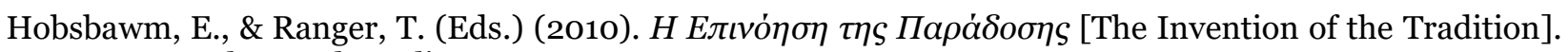
Athens: Themelio.

Kamouzis, D. (2016). Collective Representation, Memory and Refugee Identity: Asia Minor Greeks After 1923, Athens: Center for Asia Minor Studies. Published in Turkish: Kamouzis, D. (2016).

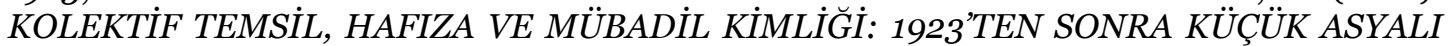
RUMLAR. Yılında Türk-Yunan Zorunlu Nüfus Mübadelesi Yeni Yaklaşımlar. Istanbul: Yeni Bulgular.

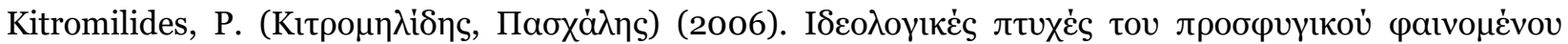

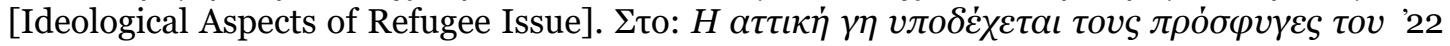
[In: Attica Land Welcomes Refugees of '22]. Karapanou, Anna (Ed.). Athens: The Hellenic Parliament Foundation.

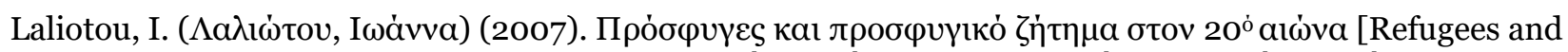

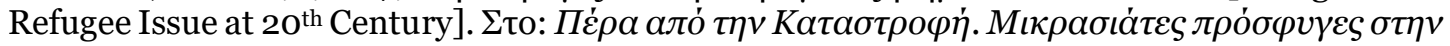

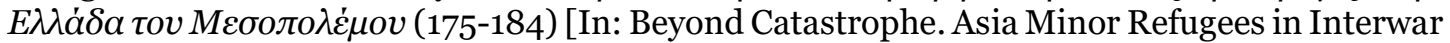
Greece (pp. 175-184). Tsedopoulos, George (Ed.). Foundation of the Hellenic Word. Athens: $2^{\text {nd }}$ Edition.

Law 281/1914 "about associations", Government's Newspaper 171(1914), 893-899. Regulates for the first time the status of associations.

Mavrogordatos, G. (1983). Stillborn Republic: Social Coalitions and Party Strategies in Greece, 1922-1936, Berkeley: University of California Press.

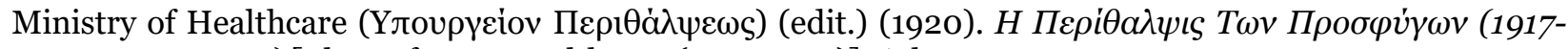
1920) [The Refugees Healthcare (1917-1920)]. Athens.

Mytilene's Sorority School, Register of pupils 1914-1915 and 1915-1916. Greek State Archives, Department of Lesvos.

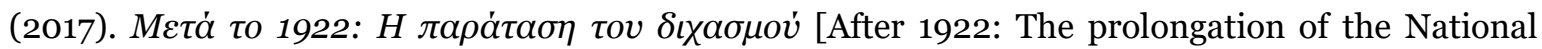
Schism]. Athens: Patakis.

Nora, P. (1989). Between Memory and History: Les Lieux de Mémoire. Representations, 26, pp. 7-24.

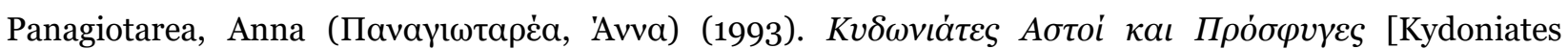

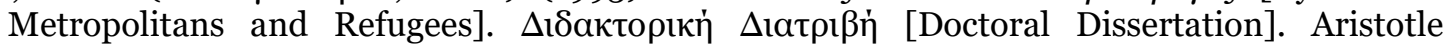
University of Thessaloniki.

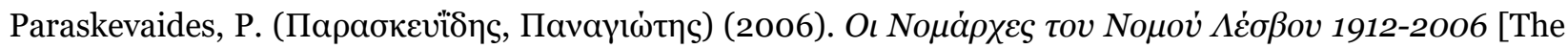
Prefects of Prefecture of Lesvos]. Mytilene: Prefecture of Lesvos.

Pentzopoulos, D. (1962). The Balkan Exchange of Populations and Its Impact on Greece, Paris: Muton.

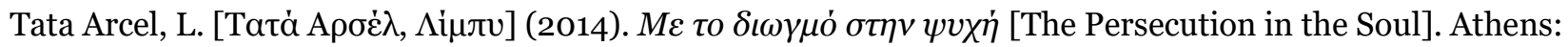
Kedros.

White, H. (2014). The Practical Past. Evanston: Northwestern University Press.

(2010). The Practical Past. Historein, 10, 10-19. https://doi.org/10.12681/historein.2.

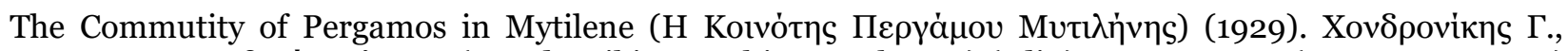

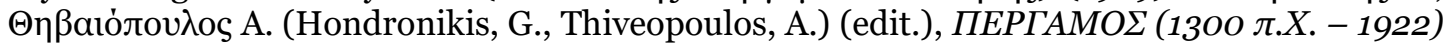
[PERGAMOS (130o b.C. - 1922)], Mytilene: Melissa.

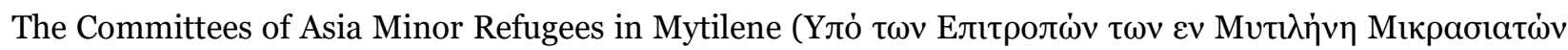

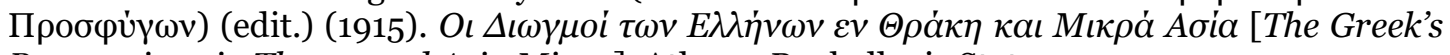
Persecutions in Thrace and Asia Minor]. Athens: Panhellenic State. 


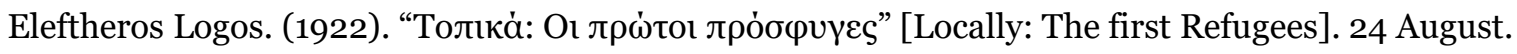

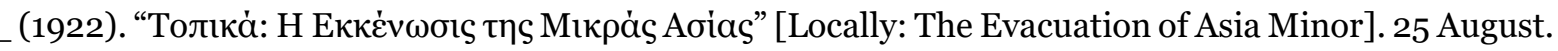

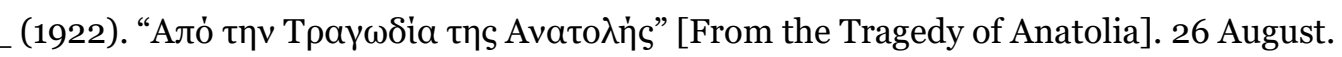

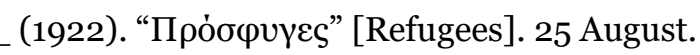

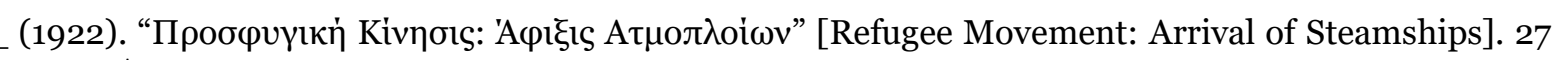
August.

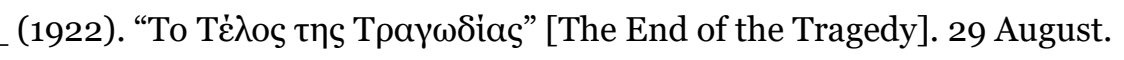

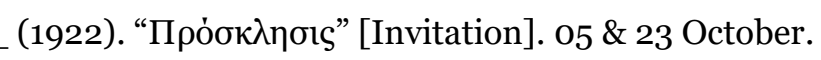

(1922). “Пробфvүıка́” [Refugee Issues]. 16 October.

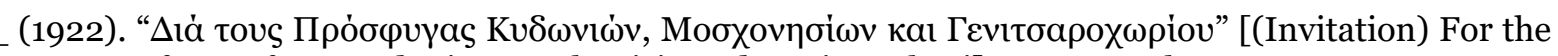
Refugees from Kydonies, Moshonisia and Genitsarohori]. 23 September.

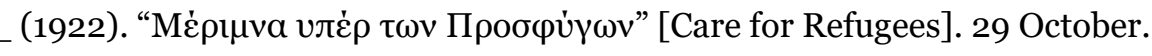

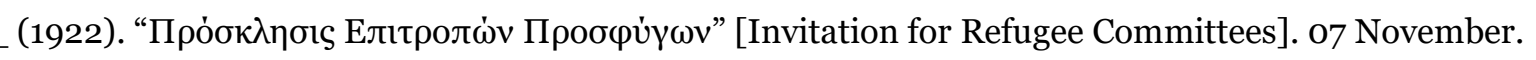

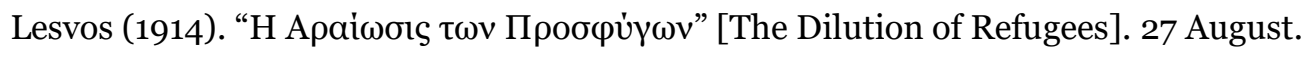

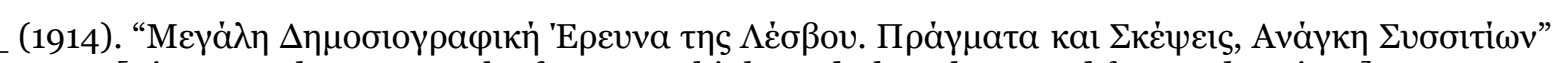

[Big Journalese Research of Lesvos. Thinks and Thoughts, Need for Food Rations]. 05 June.

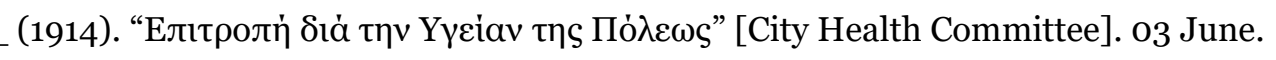

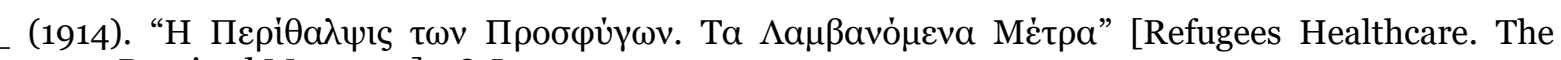
Received Measures]. 18 June.

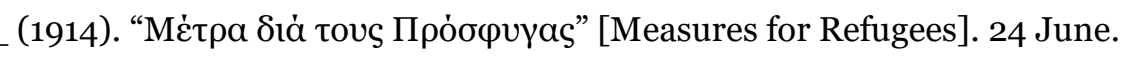

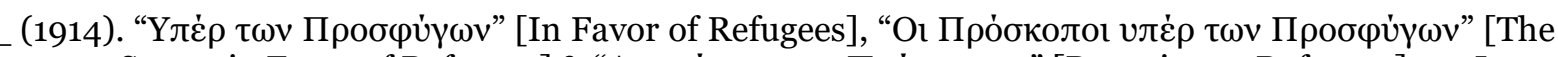
Scouts in Favor of Refugees] \& " $\Delta \omega \rho \varepsilon \alpha \dot{~ \varepsilon ı s ~ t o v s ~ П \rho o ́ \sigma \varphi v ү a s " ~[D o n a t i o n ~ t o ~ R e f u g e e s] . ~} 27$ June.

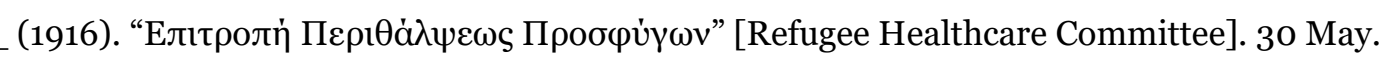

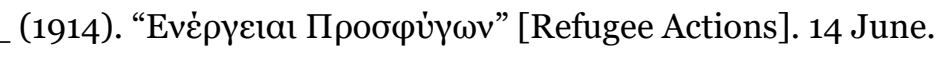

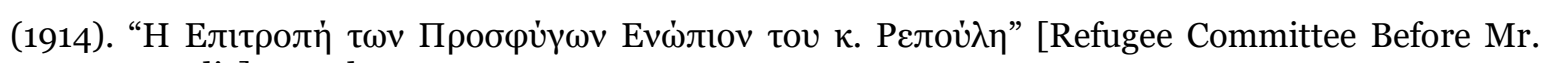
Repoulis]. 17 July.

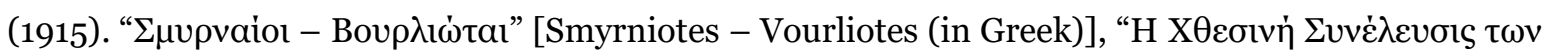

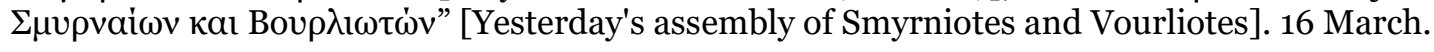

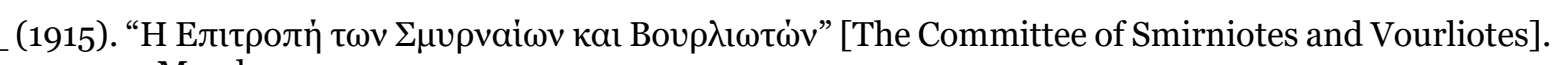
17 March.

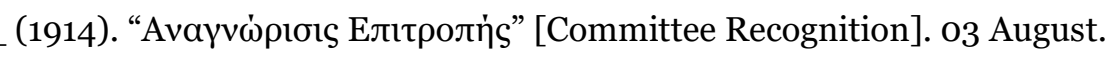

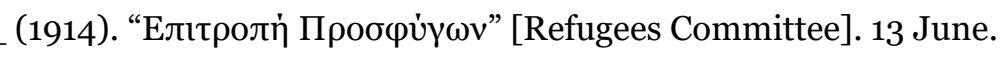

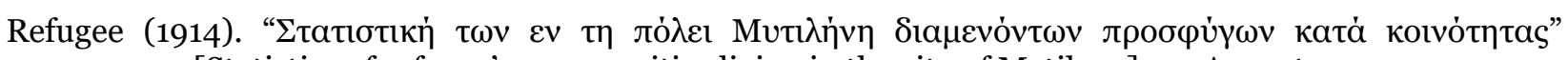
[Statistics of refugee's communities living in the city of Mytilene]. 04 August.

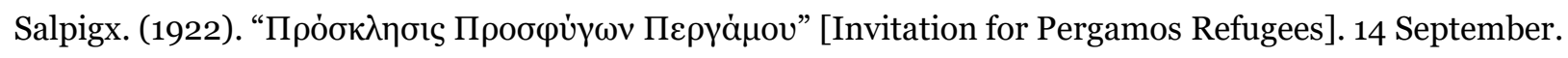

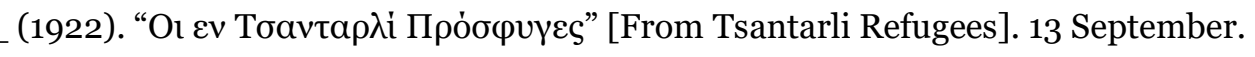

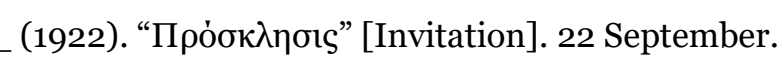

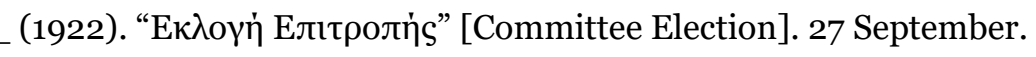

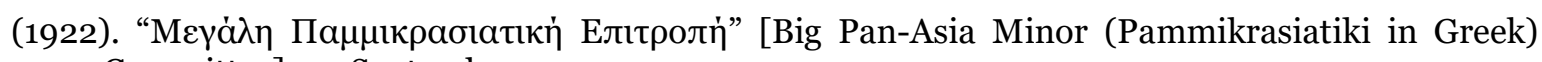
Committee]. 24 September. 
A. Pelteki- Asia Minor Refugee Associations in Lesvos (1914-1936)

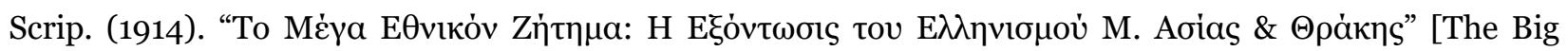
National Issue: The Extermination of Hellenism in Central Asia \&Thrace]. o9 October. 